\title{
Performance of microbial-induced carbonate precipitation on wind erosion control of sandy soil
}

\author{
M. Maleki ${ }^{1}$ S. Ebrahimi ${ }^{1}$ F. Asadzadeh ${ }^{2}$ M. Emami Tabrizi ${ }^{3}$
}

Received: 22 May 2015/Revised: 29 October 2015/Accepted: 13 December 2015/Published online: 7 January 2016

(C) Islamic Azad University (IAU) 2015

\begin{abstract}
Wind erosion is a serious problem throughout the world which results in soil and environment degradation and air pollution. The main objective of this study was to evaluate feasibility of microbial-induced carbonate precipitation, as a novel soil-strengthening technique, to reduce wind erosion risk of a sandy soil. For this purpose, the erosion of biocemented soil samples was investigated experimentally in a wind tunnel under the condition of wind velocity of $45 \mathrm{~km} \mathrm{~h}^{-1}$. The weight loss of treated samples relative to the weight loss of control treatment was 1.29 and $0.16 \%$ for low and high bacterial mix concentrations, respectively, indicating a significant improvement in erosion control in biologically treated samples. The effect of biological treatment on wind erosion control was even superior at the higher velocities. Thereafter, the penetration resistance of the surface layers as a simple index of resistance against wind erosion was measured. Significant improvements in the penetration resistance of the treated soil samples were observed. Although low bacterial mix concentrations did not significantly improve the penetration resistance of the samples, significant improvements in the penetration resistance of the treated soil samples were observed reaching to the highest measured strength $(56 \mathrm{kPa})$ in high bacterial mix concentrations samples. Finally, the morphology of precipitated
\end{abstract}

S. Ebrahimi

sirous.ebrahimi@epfl.ch

1 Biotechnology Research Center (BRC), Faculty of Chemical Engineering, Sahand University of Technology, Tabriz, Iran

2 Department of Soil Sciences, Faculty of Agriculture, Urmia University, Urmia, Iran

3 Department of Civil Engineering, Sahand University of Technology, Tabriz, Iran
$\mathrm{CaCO}_{3}$ crystals using scanning electron microscopy and $\mathrm{X}$-ray powder diffraction analysis showed that the $\mathrm{CaCO}_{3}$ was mainly precipitated as vaterite crystals forming pointto-point contacts between the sand granules.

Keywords Biocement - Microbial-induced carbonate precipitation - Soil treatment · Wind erosion control . Urease

\section{Introduction}

Wind erosion is one of the main factors in soil and environment degradation, air pollution, and suspended particles transport in arid and semiarid areas (Han et al. 2007; Movahedan et al. 2012). Migration of sand dunes by wind force is a major cause of desertification process changing agricultural areas into wasteland and covering everything up with sterile sand. Dunes have low cohesion and lack of structure. Winds with velocities greater than $5.3 \mathrm{~m} \mathrm{~s}^{-1}$ can transport sand on dunes during wind erosion process resulting in low agricultural productivity. This in time produces dust that obscures visibility, endangers human health and pollutes the air and surface waters (Diouf et al. 1990). Although wind erosion may occur in humid climates, it is more prevalent in semiarid to arid lands. Therefore, due to the environmental considerations, control of wind erosion in these areas is of great importance (Fryrear and Skidmore 1985).

There are different methods to control wind erosion and consequently fugitive dust generation. These methods are frequently classified into three categories (Goudie and Middleton 2006; Movahedan et al. 2012): agronomic methods (using living vegetation or the residues from harvested crops as windbreak), mechanical methods 
(creation of barriers to wind flow such as fences and windbreaks) and surface layer reinforcement (using soil stabilizers such as petroleum mulches and polymeric materials). Agronomic methods are difficult because soils can be agriculturally unsuitable. In addition, the winds tend to uproot young plants or bury them with drifting sand. Furthermore, these methods require extensive growing period and are not suitable for agriculture application in arid and dry lands (Diouf et al. 1990). The use of meshes or membranes is ineffective due to warping and curling of the edges. Additionally, the creation of turbulence in their lee can reduce their effective protection (Goudie and Middleton 2006). Applications of surface layer reinforcement are preferred especially to reduce the execution time and costs of the surface stabilization (He et al. 2008). These methods include using water, oil and chemical soil stabilizers (Armbrust and Lyles 1975; Lyles et al. 1974). However, the aforementioned methods introduce synthetic and toxic materials into the subsurface with significant environmental impacts (Armbrust and Dickerson 1971).

Generally, the impressionability of soil surface layer by wind is a key factor in wind erosion control. In this respect, physical soil crust formation can strongly reduce the risk of wind erosion. For instance, Gillette et al. have reported that clay and calcium carbonate content enhances crust formation on sandy soils. Formation of crust layer increases the threshold friction velocity and consequently the amount of wind drag required to initiate erosion (Gillette et al. 1980, 1982).

Recently, a relatively green and sustainable process has been developed as a novel soil treatment technique to modify soil properties such as strength, stiffness, and permeability (DeJong et al. 2010). This technique termed as MICP is a natural biologically mediated method. Because of its simplicity and the lack of an excess proton production, in most of the applications of MICP to date, urea hydrolyzing bacteria are used (Whiffin et al. 2007). In MICP by urea hydrolysis, the bacterial cells or purified urease enzyme catalyzes hydrolysis of urea into ammonium and carbonate (Reaction 1 ). The produced carbonate ions readily precipitate $\mathrm{CaCO}_{3}$ in the presence of a calcium source (Reaction 2).

$$
\begin{aligned}
& \mathrm{CO}\left(\mathrm{NH}_{2}\right)_{2}+2 \mathrm{H}_{2} \mathrm{O} \rightarrow 2 \mathrm{NH}_{4}^{+}+\mathrm{CO}_{3}^{2-} \\
& \mathrm{Ca}^{2+}+\mathrm{CO}_{3}^{2-} \rightarrow \mathrm{CaCO}_{3}(\mathrm{~s})
\end{aligned}
$$

Various studies have been performed so far in which MICP is used for improving resistance to liquefaction (Montoya et al. 2013), improving foundation bearing capacity and slope stability (van Paassen et al. 2010; Whiffin et al. 2007), creating water-impermeable crust on sand surface (Stabnikov et al. 2011), healing cracks in concrete and masonry (Bang et al. 2010; Amidi and Wang 2015), treating waste (Chu et al. 2009), immobilizing heavy metals (Fujita et al. 2010), performing shallow carbon sequestration (Washbourne et al. 2012), promoting the fine tailings consolidation (Liang et al. 2015), and improving the compressibility and shear strength of organic soil (Canakci et al. 2015).

In particular, MICP process recently has been explored as a potential dust suppressant when applied to the surfaces of different soils including silt and clay soils (Bang and Bang 2011; Meyer et al. 2011). This work is an extension of previous studies to test the effect of MICP process. Here, MICP focuses mainly on wind erosion control in sandy soil, especially in the arid and semiarid regions where the native vegetation cannot supply sufficient residues for wind erosion control. The potential application of MICP reducing wind erosion of a sandy soil was studied using Sporsarcina pasteurii. A wind tunnel experiment was adopted to study the effectiveness of MICP process in controlling wind erosion. Then, the penetration resistance of the biologically treated samples was tested as a simple index of soil surface layer resistance. Finally, morphology of precipitated $\mathrm{CaCO}_{3}$ crystals was studied using scanning electron microscope (SEM) and X-ray diffraction (XRD) analysis.

\section{Materials and methods}

\section{Medium}

In the MICP processes, $S$. pasteurii from Persian Type Culture Collection (PTCC 1645) was used as the ureasepositive bacterium. Cultivation of the microorganism was conducted in a medium containing $10 \mathrm{~g}^{-1}$ yeast extract, $5 \mathrm{~g} \mathrm{l}^{-1} \mathrm{NH}_{4} \mathrm{Cl}$ and $1.3 \mathrm{mg} \mathrm{l}^{-1} \mathrm{NiCl}_{2}$ at a $\mathrm{pH}$ value of 8.5 .

Sporsarcina pasteurii was grown to late exponential phase to final concentration of $1.5 \mathrm{~g}$ dry weight $1^{-1}$ and urease activity of $2.2 \mathrm{mM}$ urea $\mathrm{min}^{-1}$ under aerobic batch conditions. Broth cultures were incubated in a shaker incubator (3020 DR, Fanavaran Sahand Azar. CO, Iran) operated at $200 \mathrm{rpm}$. Cementation solution of MICP consisted of $\mathrm{CaCl}_{2}$ and urea. All experiments were performed at an ambient temperature of $25^{\circ} \mathrm{C} \pm 2$.

\section{Experimental design}

A sample of sandy soil with approximately $95 \%$ sand and $5 \%$ silt was provided from the surface $(0-10 \mathrm{~cm}$ depth) of sand dunes near Yazd Desert, central Iran $(\mathrm{pH} \approx 8)$. The wind erosion experiment was conducted in a wind tunnel 
Table 1 Summary of different treatments of sandy soil

\begin{tabular}{|c|c|c|}
\hline Treatment & $\begin{array}{l}\text { Concentration } \\
\text { of urea- } \mathrm{CaCl}_{2} \\
\text { medium }(\mathrm{M})\end{array}$ & Details \\
\hline Control & 0 & Tap water \\
\hline MICP_1 & 0.1 & \multirow{4}{*}{$\begin{array}{l}\text { Bacterial suspension with } \\
\mathrm{C}_{\text {Biomass }} \cong 1.5 \mathrm{~g} \text { dry } \\
\text { weight } \mathrm{l}^{-1} \text { and urease } \\
\text { activity } \cong 2.2 \mathrm{mM} \text { urea } \\
\text { min }^{-1}\end{array}$} \\
\hline MICP_2 & 0.25 & \\
\hline MICP_3 & 0.5 & \\
\hline MICP_4 & 1 & \\
\hline
\end{tabular}

with dimensions of $0.25 \times 0.25 \times 4 \mathrm{~m}$ in which wind velocities of $10-55 \mathrm{~km} \mathrm{~h}^{-1}$ can be applied. The sample tray with size of $0.03 \times 0.15 \times 0.15 \mathrm{~m}$ was placed on the floor of the working section, $3 \mathrm{~m}$ away the entry of the wind tunnel. The soil samples were treated with MICP using equimolar cementation solutions, including MICP_1 (0.1 M urea-0.1 $\left.\mathrm{M} \mathrm{CaCl}_{2}\right), \mathrm{MICP} \_2(0.25 \mathrm{M}$ urea-0.25 M $\left.\mathrm{CaCl}_{2}\right), \mathrm{MICP} 3\left(0.5 \mathrm{M}\right.$ urea-0.5 $\left.\mathrm{M} \mathrm{CaCl}_{2}\right)$ and MICP_4 (1 $\mathrm{M}$ urea-1 $\mathrm{M} \mathrm{CaCl}_{2}$ ), while samples treated with water served as control (Table 1).

For MICP processes, $100 \mathrm{ml}$ of the mixture of the bacterial mix containing $50 \mathrm{ml}$ bacterial suspension and $50 \mathrm{ml}$ cementation solution (urea- $\mathrm{CaCl}_{2}$ ) was uniformly sprayed on the soil surface with three replicates $(100 \mathrm{ml}$ was equivalent to pore volume of $1 \mathrm{~cm}$ of top layer of soil samples). The treated samples were allowed to be air-dried for about four days in the laboratory condition, and then, wind experiments were conducted.

The samples were exposed to different wind velocities for $5 \mathrm{~min}$, and weight loss of the samples was measured. Comparison of the mean values was made using one-way ANOVA $(P=0.05)$. Statistical Software SPSS 12.0 was used for this purpose.

For SEM and XRD analysis of consolidated minerals, a thin sliced section was prepared from biocementated sand column. The samples were analyzed with SEM (CamScan MV2300, Canada) and XRD (powder X-Ray Diffractometer, Bruker, D8ADVANCE, Germany) to follow calcium carbonate precipitation patterns.

\section{Results and discussion}

In order to induce MICP in the soil surface, bacteria and substrates have to be sprayed onto the porous material. In this study, bacterial suspension and cementation solution were mixed and immediately sprayed on the surface of the soil samples. Simultaneous injection of bacteria and reagents at low flow rates or high urease activity can result in full clogging of the system near the injection point (Stocks-Fischer et al. 1999; Whiffin et al. 2007). Therefore,

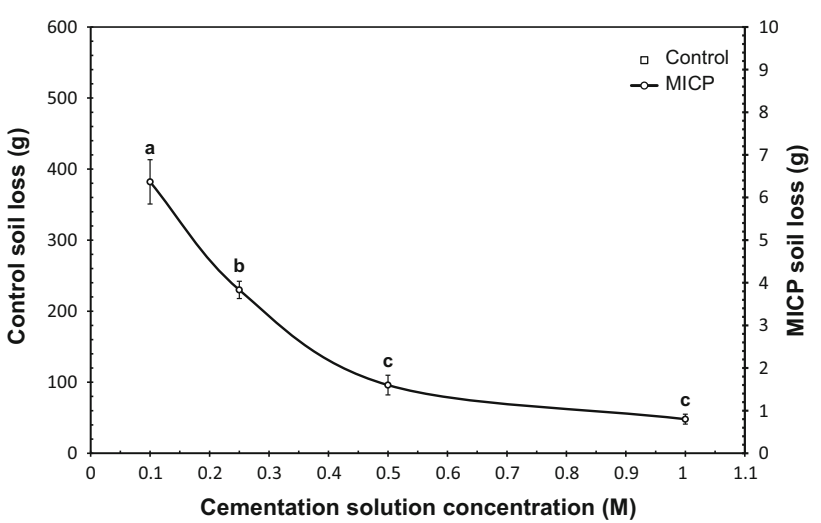

Fig. 1 Soil loss of treatments at different cementation solution concentration. Different letters for a given internode indicate significant $(P<0.05)$ differences among treatments assessed by 1.s.d. tests

injection time of bacterial mix should be fast enough to prevent reaction progress before injection.

Figure 1 illustrates the weight loss of MICP-treated samples and control treatment. These results show that the biocementation of samples by MICP at different concentrations has a very significant impact on the decrease in soil loss amount. The weight loss of MICP-treated samples relative to the weight loss of control treatment was 1.29 and $0.16 \%$ for MICP_1 and $\mathrm{MICP}_{-} 4$, respectively. Differences between MICP treatments were tested statistically at a $5 \%$ significance level according to 1.s.d. tests. Accordingly, at the high concentration of the bacterial mix, the amount of weight loss is negligible. However, when concentration of bacterial mix is reduced, the amount of loss increases. When the concentration of cementation solution increases from 0.5 to $1 \mathrm{M}$ (MICP_3 and MICP_4), decrease in weight loss is not significant. Low difference between the MICP_3 and MICP_4 treatments might be explained by urease activity inhibition at high concentration of $\mathrm{CaCl}_{2}$ and saturation of surface coverage.

It is already shown that increasing calcium concentration from 1 to $2 \mathrm{M}$ results in inhibition of urease activity (Al-Thawadi 2008). Another explanation for negligible reduction in erosion amount at high bacterial mix concentration could be because of limited bond-making area. The limited bond-making area is defined as the possible binding points between sand grains which play the main role in the soil aggregation (DeJong et al. 2010). As a result, total area does not matter for strength production as much as limited bond-making area.

\section{Effect of wind velocity on weight loss}

Because of small difference between $\mathrm{MICP} \_3$ and MICP_4, the former was tested at different wind velocities 


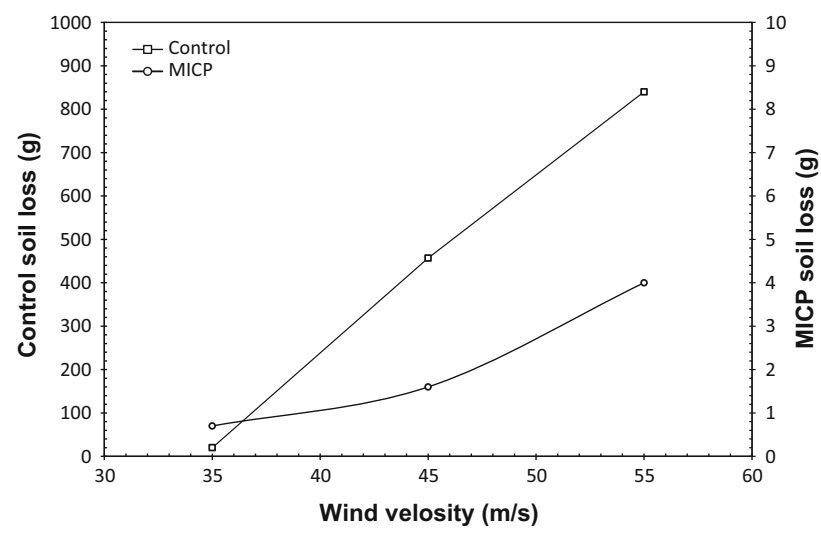

Fig. 2 Soil loss of treatments at different cementation solution concentration. Different letters for a given internode indicate significant $(P<0.05)$ differences among treatments assessed by 1.s.d. tests

as a desirable treatment and compared with the control treatment, due to economical considerations (Fig. 2).

In the control treatment, the soil loss increased sharply from 20 to $840 \mathrm{~g}$ in the velocities of 35 and $55 \mathrm{~km} \mathrm{~h}^{-1}$, respectively. The results also show that the soil loss of MICP_3 increased exponentially with velocity a value of about $4 \mathrm{~g}$ in velocity of $55 \mathrm{~km} \mathrm{~h}^{-1}$. Furthermore, differences in erosion amount between biological and control treatments have a direct relation with wind velocity. However, decrease in erosion relays between 96.5 and $99.5 \%$. This reveals that the biological treatment on the soil surface can effectively reduce the erosion amount, even greater at the higher velocities.

\section{Penetration resistance}

Penetration resistance of the surface layer as a simple index of resistance against wind erosion was measured using micro-penetrometer for all treatments in air-dried condition at 1-cm surface layer of the samples (Fig. 3).

The results obtained by determining the penetration resistance of the test specimens are illustrated in Fig. 4. The results show that the penetration resistance of samples enhanced with the increase in the bacterial mix concentration. This improvement is simply due to $\mathrm{CaCO}_{3}$ crystal formation on the surface layer of the samples. Amount of crystals $\left(\mathrm{CaCO}_{3}\right.$ precipitates) can be theoretically calculated, assuming precipitation only occurred on 1-cm top layer of the surface in which the volume of soil is equal to $225 \mathrm{~cm}^{3}$. From these calculations, the crystal amount was found to be in the range of 0.5 to $5 \mathrm{~g}$ per $\mathrm{cm}^{3}$ of soil at different cementation solution concentrations.

However, low bacterial mix concentrations (MICP_1) did not significantly improve the penetration resistance of the samples. In addition, there was no significant difference

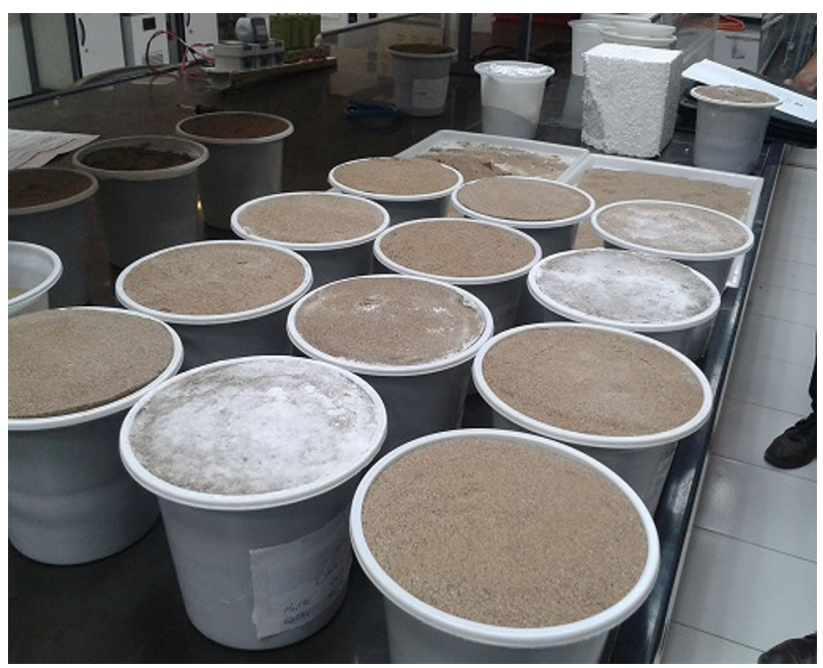

Fig. 3 Treated samples with different concentration of bacteria and reagent for penetration resistance experiment

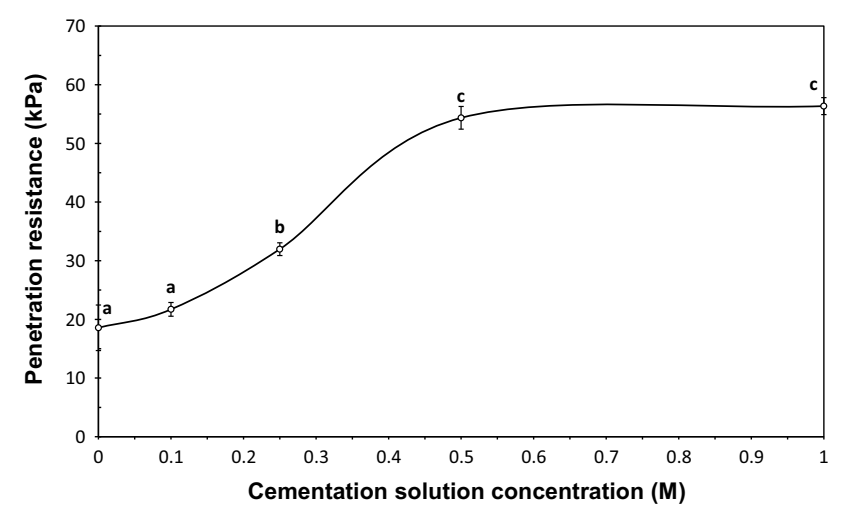

Fig. 4 Penetration resistance of treatments at different cementation concentration. Different letters for a given internode indicate significant $(P<0.05)$ differences among treatments assessed by 1.s.d. tests

between control and MICP_1 treatments. This could be due to the fact that inside the soil porosity, the bacteria could not produce enough crystals to induce a measurable change in the mechanical properties $\left(0.5 \mathrm{~g} \mathrm{CaCO}_{3}\right.$ per $\left.\mathrm{cm}^{3}\right)$. At higher bacterial concentration, there was a significant improvement in surface layer penetration resistance reaching to the highest measured strength $(56 \mathrm{kPa})$ in MICP_4 samples. However, there was no significant difference in the penetration resistance of the samples between the MICP treatments at the high concentrations of the bacterial mix (MICP_3 and MICP_4).

Although the precipitated amount of $\mathrm{CaCO}_{3}$ for MICP_4 is theoretically expected to be twice as much as MICP_3, the resistance similarity might be caused by distribution of $\mathrm{CaCO}_{3}$ crystal around soil particles rather than particleparticle contacts at the high concentration of bacterial mix 
(DeJong et al. 2010). Accordingly, the bonding between the two particles by calcite is relatively small and insignificant improvement for soil properties may be obtained.

\section{Relation between erosion loss and penetration resistance}

Figure 5 shows the relation between the measured average penetration resistance and soil loss by erosion. Rather interestingly, the relationship, although not extremely strong, is negative since erosion loss often decreases with increasing penetration resistance. Consequently, MICP appeared to have some beneficial impact in the formation of the aggregate structure in sandy soils. It has also naturally high aggregate stability when used in soils (Fig. 5), which is also a main reason to control wind erosion.

Literature review shows that for controlling wind erosion, mulches such as clay and lime (Diouf et al. 1990), polyvinyl acetate (Movahedan et al. 2012), and ligninbased binder (Shulga and Betkers 2011) have been used. Wind velocity difference, together with physical properties of soil and mulch, has made it difficult to comprehensively and technically compare the treatments with the literature. However, MICP can be introduced as an advantageous method for its durability and $\mathrm{CaCO}_{3}$ precipitates formation (almost insoluble in water). Additionally, MICP is recognized as an environmentally friendly method. The final concentration of $\mathrm{CaCl}_{2}$ used in this study was $7.5 \%$ $(500 \mathrm{mM})$ for MICP_3, approximately 5 times less than the concentration $(38 \%)$ currently allowed to use commercially (Lohnes and Coree 2002). In addition, the concentrations of $\mathrm{NH}_{4} \mathrm{Cl}(5.4 \%)$ and urea (3\%) for MICP_3 were much lower than a urea content allowed (43\%) for commercial use as a hoarfrost protectant pesticide without any evidence of adverse persistent effects (Meyer et al. 2011).

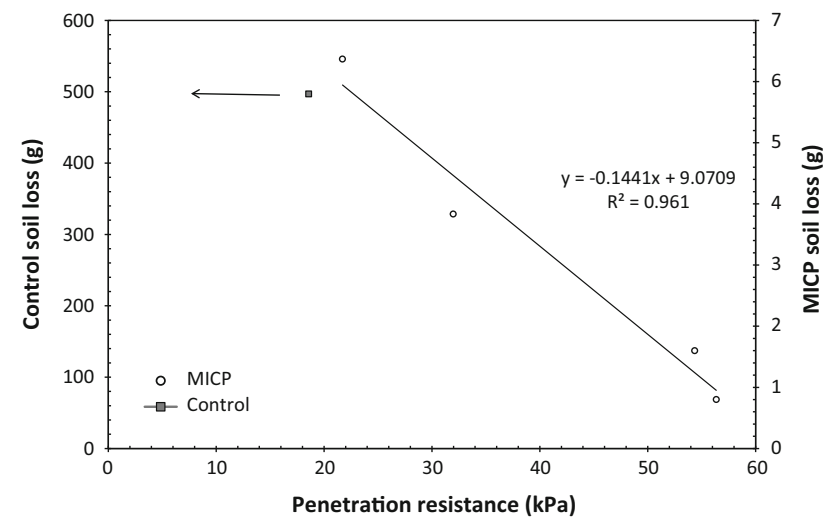

Fig. 5 Relationship between soil loss and penetration resistance

\section{Morphology of biologically cemented samples}

Thin and dense crust, with thickness approximately $1 \mathrm{~cm}$, was formed on the surface of the treated sandy soil (Fig. 6). XRD analysis of samples in solid phase is depicted in Fig. 7. The XRD results have been compared with typical diffraction spectra for calcite and vaterite in the previous studies (e.g., as in (Lian et al. 2006) From the XRD results, the quantification of relative abundances of the different $\mathrm{CaCO}_{3}$ minerals were carried out by comparing the ratios of the integral area of the major characteristic peaks with measured ratios in a sample of known composition. XRD analysis of the precipitate shows a mineral composition of about $93 \%$ vaterite and $7 \%$ calcite.

The homogeneity of the $\mathrm{CaCO}_{3}$ crystal precipitation was evaluated by SEM. The morphology of the consolidated soil samples examined under SEM is depicted in Fig. 8a-f, where crystals of distinct $\mathrm{CaCO}_{3}$ precipitates were grown between sand grains. In Fig. 8a, b, it was obvious that the amount of $\mathrm{CaCO}_{3}$ precipitation was very high, making the

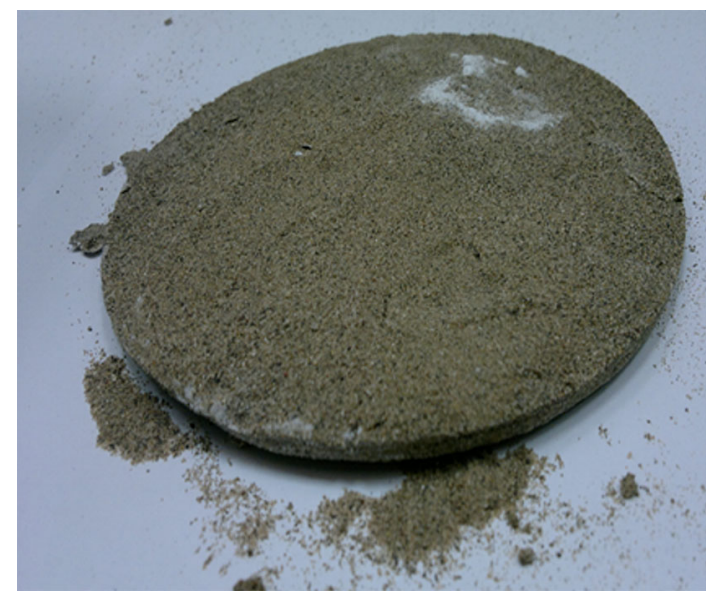

Fig. 6 Biologically treated sample (MICP_3) after breaking the surface layer prepared for SEM analysis

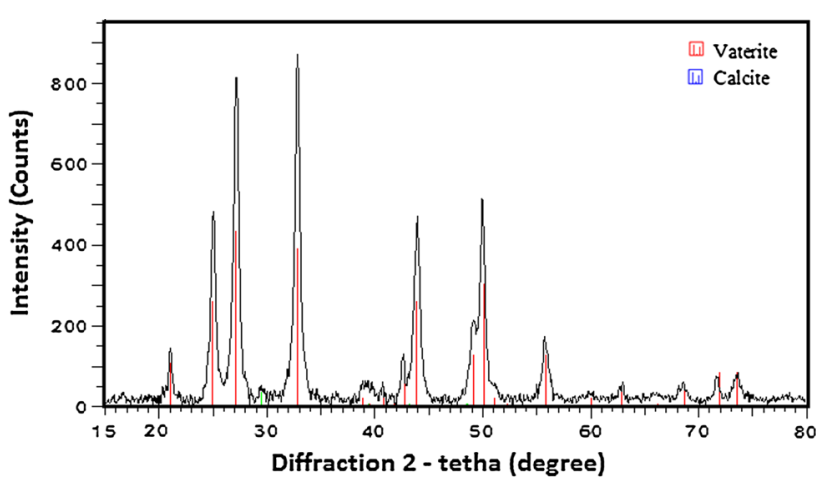

Fig. 7 XRD quantitative analysis of the final weight fractions of sand samples 
Fig. 8 SEM images of a sample of sandy soil containing calcium carbonate crystals formed by MICP process: $\mathbf{a}, \mathbf{b}$ sand grains are hard to recognize as they are fully covered with a thin layer of crystals, c various crystal shapes, sizes and distributions were observed, $\mathbf{d}-\mathbf{f}$ bacterial stamps leaving holes in the crystalline structure are clearly visible, at $2000 \times, 4000 \times$ and $6000 \times$ magnification, respectively, the sand grains are covered with dissected spheres (likely vaterite) up to $40 \mu \mathrm{m}$ thick and a sheet of agglomerated rhombohedral crystals (likely calcite)
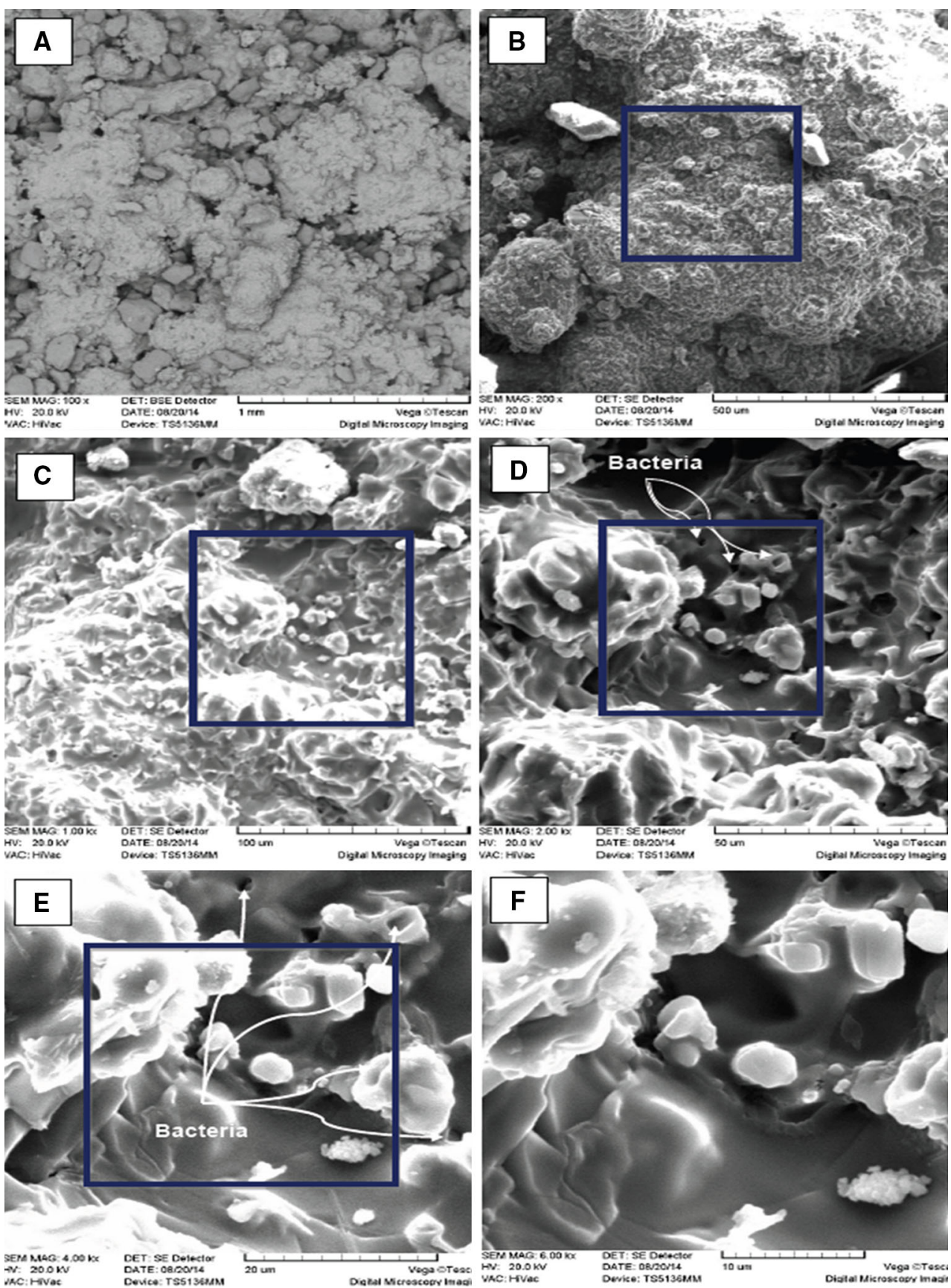

sand granules hard to be distinguished under SEM. At the higher magnification (Fig. 8c), various crystal shapes, sizes, and distributions were observed. Bacterial stamps leaving holes in the crystalline structure are evidently visible (Fig. 8d, e). At the highest magnification (Fig. 8f), the sand grains are covered with dissected spheres (likely vaterite) up to $40 \mu \mathrm{m}$ and a sheet of agglomerated rhombohedral crystals (likely calcite).

It has been reported that at high urease activity (90-180 mM urea $\mathrm{h}^{-1}$ ) vaterite is kinetically favored over calcite growth, while at low urease activity, calcite is predominant (Kralj et al. 1990). When urea gets depleted causing the urease activity to decrease, calcite growth becomes kinetically favored over vaterite. This might be the reason for the presence of calcite at higher urease activity (Van Paassen 2009). With initial urease activity 120-130 $\mathrm{mM}$ urea $\mathrm{h}^{-1}$ (this study), $1 \mathrm{M}$ urea is consumed within $8 \mathrm{~h}$. A drop in urease activity might also explain the occurrence of little calcite crystals beside the vaterite as seen in Fig. 7d. In addition, vaterite formation occurred at higher $\mathrm{pH}$ values (9.5), yet calcite was formed at lower $\mathrm{pH}$ values (8.5) at room temperature. In our study, $\mathrm{pH}$ 
exceeded 9.5 due to ammonium production during urea hydrolysis (Warren et al. 2001).

On the other hand, both biofilm formation and local super-saturation play important role in the precipitation of $\mathrm{CaCO}_{3}$ crystals. Application of bacteria resulted in the formation of a biofilm on the surface. This biofilm acted as a primer for the carbonate coating, as bacteria inside the biofilm act as nucleation sites due to the negative charge of their cell wall (Hammes and Verstraete 2002). In the presence of calcium ions, the bacterial activity resulted in the super-saturation of the liquid phase (De Muynck et al. 2008). This super-saturation later resulted in the precipitation of calcium carbonate crystals on the biofilm. The $\mathrm{CaCO}_{3}$ crystals were also precipitated inside the pores in which biofilm had not formed. This implies that the $\mathrm{CaCO}_{3}$ precipitation was heterogeneously occurred on soil surface, as shown in Fig. 8.

According to Warren et al. (2001) vaterite formation commonly occurs presumably by heterogenous nucleation and precipitation. Furthermore, vaterite crystallization actively encouraged by the products of bacterial metabolism or EPS comes to play during biofilm formation. The combined effect affords vaterite to be a main component in the resultant carbonate mineral assembly formed. The results obtained from XRD and SEM analysis of the precipitates confirm these issues and show that the main portion of formed $\mathrm{CaCO}_{3}$ is vaterite.

\section{Conclusion}

In this research, based on microbial-induced carbonate precipitation (MICP), an alternative soil conservation method was investigated for sandy soil. The results indicated that application of MICP in soil surface can be an effective alternative for the soil wind erosion control, especially at higher velocities. Thereafter, penetration resistance of the surface layer as a simple index of resistance against wind erosion was measured. Establishment of a relationship between erosion amount and penetration resistance for all samples suggested that the formation of the aggregate structure by MICP process could reduce the erosion amount remarkably and provide sand dune fixation for dust control and future re-vegetation. This field is still young compared to the conventional methods used to control the erosion, so the goal of this study was more to introduce a controlling method for erosion in sandy soils. Still, substrates switching from expensive yeast extract to more economical substrates such as corn steep liquor and molasses must be focused in later studies.

Acknowledgments The authors are thankful to department of Soil Sciences, Urmia University, Iran, for the experimental facilities.

\section{References}

Al-Thawadi S (2008) High strength in-situ biocementation of soil by calcite precipitating locally isolated ureolytic bacteria. Phd Thesis, Murdoch University

Amidi S, Wang J (2015) Surface treatment of concrete bricks using calcium carbonate precipitation. Constr Build Mater 80:273-278

Armbrust D, Dickerson J (1971) Temporary wind erosion control: cost and effectiveness of 34 commercial materials. J Soil Water Conserv 26:154-157

Armbrust D, Lyles L (1975) Soil stabilizers to control wind erosion. Soil Cond 7:77-82

Bang SC, Bang SS (2011) KGS Awards Lectures: application of microbiologically induced soil stabilization technique for dust suppression. Int J Geo-Eng 3:27-37

Bang S, Lippert J, Yerra U, Mulukutla S, Ramakrishnan V (2010) Microbial calcite, a bio-based smart nanomaterial in concrete remediation. Int J Smart Nano Mater 1:28-39

Canakci H, Sidik W, Kilic IH (2015) Effect of bacterial calcium carbonate precipitation on compressibility and shear strength of organic soil. Soils Found 55:1211-1221

Chu J, Ivanov V, Lee M, Oh X, He J (2009) Soil and waste treatment using biocement. In: Proceedings of the international symposium on ground improvement technologies and case histories, ISGI, vol 9, pp 165-170

De Muynck W, Debrouwer D, De Belie N, Verstraete W (2008) Bacterial carbonate precipitation improves the durability of cementitious materials. Cem Concr Res 38:1005-1014

DeJong JT, Mortensen BM, Martinez BC, Nelson DC (2010) Biomediated soil improvement. Ecol Eng 36:197-210

Diouf B, Skidmore E, Layton J, Hagen L (1990) Stabilizing fine sand by adding clay: laboratory wind tunnel study. Soil Technol 3:21-31

Fryrear DW, Skidmore E (1985) Methods for controlling wind erosion. In: Soil erosion and crop productivity, Madison: American Society of Agronomy, Crop Science Society of America, Soil Science Society of America, pp 443-457

Fujita Y, Taylor JL, Wendt LM, Reed DW, Smith RW (2010) Evaluating the potential of native ureolytic microbes to remediate a $90 \mathrm{Sr}$ contaminated environment. Environ Sci Technol 44:7652-7658

Gillette DA, Adams J, Endo A, Smith D, Kihl R (1980) Threshold velocities for input of soil particles into the air by desert soils. J Geophys Res Oceans (1978-2012) 85:5621-5630

Gillette DA, Adams J, Muhs D, Kihl R (1982) Threshold friction velocities and rupture moduli for crusted desert soils for the input of soil particles into the air. J Geophys Res Oceans (1978-2012) 87:9003-9015

Goudie AS, Middleton NJ (eds) (2006) Desert Dust in the Global System. Springer, Heidelberg, pp 193-199

Hammes F, Verstraete W (2002) Key roles of $\mathrm{pH}$ and calcium metabolism in microbial carbonate precipitation. Rev Environ Sci Biotechnol 1:3-7

Han Z, Wang T, Dong Z, Hu Y, Yao Z (2007) Chemical stabilization of mobile dunefields along a highway in the Taklimakan Desert of China. J Arid Environ 68:260-270

He J-J, Cai Q-G, Tang Z-J (2008) Wind tunnel experimental study on the effect of PAM on soil wind erosion control. Environ Monit Assess 145:185-193

Kralj D, Brečević L, Nielsen AE (1990) Vaterite growth and dissolution in aqueous solution I. Kinetics of crystal growth. J Cryst Growth 104:793-800

Lian B, Hu Q, Chen J, Ji J, Teng HH (2006) Carbonate biomineralization induced by soil bacterium Bacillus megaterium. Geochim Cosmochim Acta 70:5522-5535 
Liang J, Guo Z, Deng L, Liu Y (2015) Mature fine tailings consolidation through microbial induced calcium carbonate precipitation. Can J Civ Eng 42:1-4

Lohnes RA, Coree B (2002) Determination and evaluation of alternate methods for managing and controlling highway-related dust. Iowa Department of Transportation

Lyles L, Schrandt R, Schmeidler N (1974) Commercial soil stabilizers for temporary wind-erosion control. Trans ASAE 17:1015-1019

Meyer F, Bang S, Min S, Stetler L, Bang S (2011) Microbiologicallyinduced soil stabilization: application of Sporosarcina pasteurii $\mathrm{N}$ for fugitive dust control. In: Geo-Frontiers 2011@ sAdvances in Geotechnical Engineering, ASCE, pp 4002-4011

Montoya B, DeJong J, Boulanger R (2013) Dynamic response of liquefiable sand improved by microbial-induced calcite precipitation. Géotechnique 63:302-312

Movahedan M, Abbasi N, Keramati M (2012) Wind erosion control of soils using polymeric materials. Eurasian $\mathrm{J}$ Soil Sci $1(2): 81-86$

Shulga G, Betkers T (2011) Lignin-based dust suppressant and its effect on the properties of light soil. In: Proceedings of the 8th international conference on environmental engineering, pp 19-20
Stabnikov V, Naeimi M, Ivanov V, Chu J (2011) Formation of waterimpermeable crust on sand surface using biocement. Cem Concr Res 41:1143-1149

Stocks-Fischer S, Galinat JK, Bang SS (1999) Microbiological precipitation of $\mathrm{CaCO}_{3}$. Soil Biol Biochem 31:1563-1571

van Paassen L (2009) Biogrout, ground improvement by microbial induced carbonate precipitation. PhD Thesis, Delft University of Technology

van Paassen LA, Ghose R, van der Linden TJ, van der Star WR, van Loosdrecht MC (2010) Quantifying biomediated ground improvement by ureolysis: large-scale biogrout experiment. J Geotech Geoenviron Eng 136:1721-1728

Warren LA, Maurice PA, Parmar N, Ferris FG (2001) Microbially mediated calcium carbonate precipitation: implications for interpreting calcite precipitation and for solid-phase capture of inorganic contaminants. Geomicrobiol J 18:93-115

Washbourne C-L, Renforth P, Manning D (2012) Investigating carbonate formation in urban soils as a method for capture and storage of atmospheric carbon. Sci Total Environ 431:166-175

Whiffin VS, van Paassen LA, Harkes MP (2007) Microbial carbonate precipitation as a soil improvement technique. Geomicrobiol J 24:417-423 